膜マイクロドメインによる成長因子受容体の制御

樺山一哉

\title{
Modulation of Growth Factor Receptors in Membrane Microdomains
}

\author{
Kazuya Kabayama \\ Institute of Glycoscience, Tokai University; 4-1-1 Kitakaname, Hiratsuka, Kanagawa 259-1292, Japan.
}

(Received October 11, 2011)

\begin{abstract}
Membrane lateral heterogeneity is accepted as a requirement for the function of biological membranes, and the notion of the "raft/microdomain" gives specificity to this concept. Recently, fluorescence-based techniques such as fluorescence recovery after photobleaching (FRAP), single particle tracking (SPT), and fluorescence correlation spectroscopy (FCS) have shown promise for application to the dynamics of membrane molecules in microdomains. We previously revealed, by performing live-cell FRAP and SPT studies, a mechanism of insulin resistance in which dissociation of the insulin receptor (IR)-caveolin-1 (Cav1) complex was caused by an interaction between the IR $\beta$ subunit and the ganglioside GM3 cluster, a glycolipid-enriched membrane microdomain. We hoped to demonstrate that an alteration in the lipid component of microdomains affects lateral diffusion of membrane receptors. We therefore established an experimental system for monitoring the membrane organization of receptors by analyzing their lateral diffusion parameters in the plasma membranes of living cells using FRAP and SPT. In this study, measurement of the lateral diffusion of the IR was performed by fitting analysis to fluorescence recovery curves and trace analysis to individual fluorescent spots, which provided the diffusion constant. The results show how fast IR molecules diffuse before and after a change in membrane environment, such as stimulation by cholesterol depression or treatment with a glycosphingolipid (GSL) inhibitor. Using these techniques, we have established a method for determining the diffusion constant for the lateral movement of IR-EGFP, expressed in CHO-K1 cells. We will use these techniques for the lateral diffusion analysis of membrane receptors under other assay conditions, such as use of GSL-deficient cells or pathologic samples.
\end{abstract}

Key words — microdomain; insulin receptor; glycolipid; ganglioside; fluorescence recovery after photobleaching

\section{1.はじめに}

膜の不均質性が生体膜において重要な役割を果た していることがこれまでの研究で実証されており， Lipid Raft（マイクロドメイン）の概念がその基盤 となっている.しかしながら，Lipid Raft 研究の分 野では解析手法が手詰まりの状態で，生体膜を時空 間に支配された液層として研究する物理的手法はま だ開発途中である。これが実際の細胞を解析する際 の生物学的手法, 物理化学的手法との間に大きな溝 を作っている.

Lipid Raft の一種, 糖脂質マイクロドメインの構 成成分として知られているガングリオシドは，シア

東海大学糖鎖科学研究所（干259-1292 神奈川県平塚市 北金目 4-1-1)

e-mail: kaba@tokai-u.jp

本総説は, 日本薬学会第 131 年会シンポジウム OS02

で発表したものを中心に記述したものである.
ル酸を含むスフィンゴ糖脂質 $(\mathrm{GSL})$ ファミリー の総称であり, GM3 はその生合成経路における最 初の分子である。GM3 はヒトを含む哺乳動物の種 々の細胞に広く発現していることから, その生理機 能及び病態生理学的意義が注目されている.ガング リオシドは細胞膜表面に発現しがん細胞の接着や浸 潤，受容体活性，増殖因子様活性，細胞間認識など に関与しており, がんの悪性度との関連においても

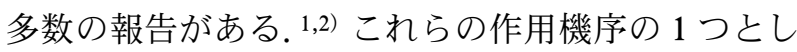
て膜受容体分子の糖脂質マイクロドメインへの集積 あるいは解離が想定されている。しかしながらその 解析手法は, ショ糖密度勾配超遠心を主軸とした 「界面活性剂に不溶性か可溶性か?」によって細胞 膜上の不均質な局在を評価する方法に留まり，この 域を脱していない.さらに，汎用される Triton X-100 のような非イオン性界面活性剂は脂質一タンパク質 相互作用を切る性質を持つため，静電的相互作用も 
考慮にいれた「膜受容体分子の糖脂質マイクロドメ インへの集積あるいは解離」の評価は困難であると 考える.

そこで筆者は界面活性剤を「使わない手法」で糖 脂質マイクロドメインの機能解明を目指し, 蛍光顕 微鏡を用いた分子動態解析を導入することを考え た。 近年, 蛍光標識分子を用いた可視化技術の発展 は目覚しく，基礎研究のみならず臨床応用も視野に 入れた分子動態解析が注目されている。なお，本総 説には一部未発表デー夕も含まれているが，詳細は 原著論文として投稿中であることをご理解頂き，拝 読願えれば幸甚である。

2. 糖脂質マイクロドメインにより制御される膜 受容体の動態解析

2-1. FRAP 法によるインスリン受容体の動的な 局在の検討筆者らは以前に, 脂肪細胞のインス リン抵抗性作用機序として，カベオリン 1 (Cav1) に結合してカベオラに局在するインスリン受容体 （IR）が，GM3 との静電的相互作用によりカべオ ラから解離しシグナルを抑制することが原因の 1 つ であることを, 光学顕微鏡による膜分子の動態観察 法を用いて実証している。研究背景の概要について は以前の報告3) 及び日本語総説4)を参照されたい.

上記の研究において細胞膜上で IR-Cav1 及び IRGM3 の相互作用を解析するために, 免疫沈降法 や, 光反応性の GM3 誘導体を用いて生化学的な検 討を行った後，生細胞イメージングによる解析法を 試みた。解析には共焦点顕微鏡による FRAP（光 退色後の蛍光回復測定）法を用いた。FRAP 法で は夕ーゲットとなる分子に蛍光標識を施すことが必 要である，細胞において分子の動態を解析したい領 域（ROI）に強いレーザーを短時間照射し，分子の 機能を壊さずに蛍光のみを退色(ブリーチ)させる. もし目的分子が不動ならば，ブリーチ領域の蛍光は 回復しない。動的な分子ならば，拡散することで， 周囲の未退色分子が混ざり合い, ブリーチ領域の蛍 光は回復していく，この時間経過にともなう蛍光回 復率をグラフにプロットすることで, 目的分子の動 的成分比率や拡散速度を算出することができる

(Fig. 1).

この手法を用いて細胞に発現させた IR-GFP 融 合タンパク質及び Cav1-RFP 融合タンパク質の動 的成分の比率を測定した。 IR-GFP 融合タンパク質

のみを発現させた HEK293 細胞において, IR-GFP の蛍光回復率は $60 \%$ でった。一方, IR-GFP と Cav1-RFP を共発現させた場合, Cav1-RFP が形成 するドット状の構造体（Cav1 が形成するカベオラ 構造と推定される) が含まれる領域においては, IRGFP の蛍光回復率は $25 \%$ 程度まで減少した。この 減少効果は, IR との結合ドメイン（スキャフォー ルドドメイン）を不活化した変異体（Cav1 ${ }^{\mathrm{F} 92 \mathrm{~A} / \mathrm{V} 94 \mathrm{~A}}$ -RFP）との共発現では起こらなかった（Fig. 2).

以上のことから, FRAP 法によって IR の動的比 率すなわち不動化した Cav1 との結合比率を測定で きることを確認した，次に，筆者らが以前に構築し ていた GM3 再構成細胞（GM3 (+)細胞）とその親 細胞 $(\mathrm{GM} 3(-) \text { 細胞 })^{5)}$ において FRAP 法を行っ た。その結果, GM3 $(+)$ 細胞において IR-GFP の 蛍光回復率が $10 \%$ 程度高かったことから, 細胞膜 上で GM3 の発現上昇が IR-Cav1 複合体の解離を促 進することが示された（Fig. 3).

2-2. GM3 が構成する脂質マイクロドメインと IR との相互作用解析 脂肪細胞において, IR と Cav1 は細胞膜内側でそれぞれの結合ドメインを介 して結合し，Cav1 を構成成分とするカべオラに局 在していることが知られている.6,7)一方, GM3 は 外膜側に存在し，非還元末端に酸性基であるシアル 酸を有している. IR は膜貫通領域の細胞外側直上 に塩基性アミノ酸のリジンを持つ. ところで，膜近 傍には電荷の勾配が存在しており, 細胞内膜では膜 脂質（酸性リン脂質ホスファチジルセリン）とCキナーゼタンパク質のリジンクラスターとの静電的 相互作用が細胞内のシグナル制御に関与しているこ とが物理化学的に実証されている（MARCKS のミ リストイル静電気スイッチ). ${ }^{8)}$ このことから, 外膜 においても GM3 が IR-Cav1 複合体に与える影響と して，GM3 と IR の静電的相互作用が考えられ た。 そこで，IR の膜貫通領域直上のリジンを他の アミノ酸残基に置換して FRAP 法を行った。その

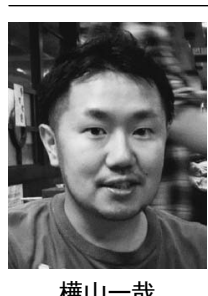

樺山一哉
東海大学糖鎖科学研究所特任准教授. 1997 年慶應義塾大学理工学部卒業, 1999 年慶應義塾大学大学院理工学研究 科修士課程修了, 2002 年北海道大学大 学院薬学研究科博士課程修了, その後 同大学博士研究員, CREST 研究員を 経て 2006 年東北薬科大学分子生体膜研 究所助手〜助教. 2009 年より現職. 


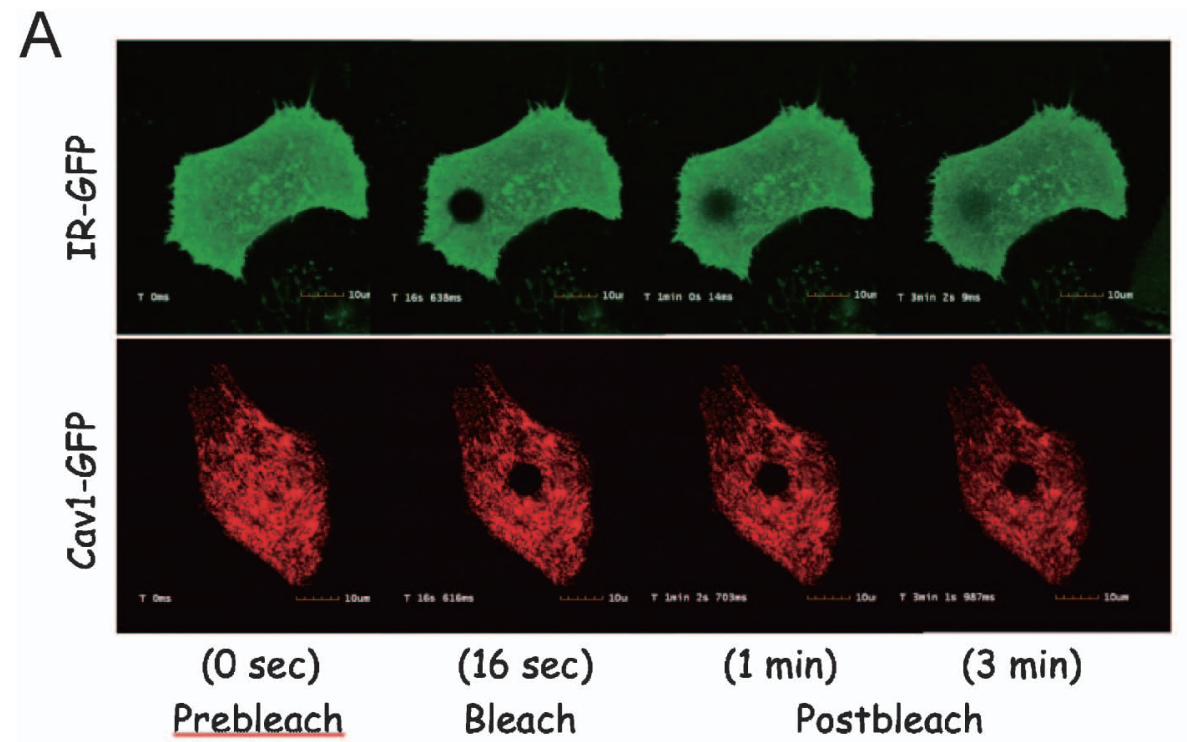

B
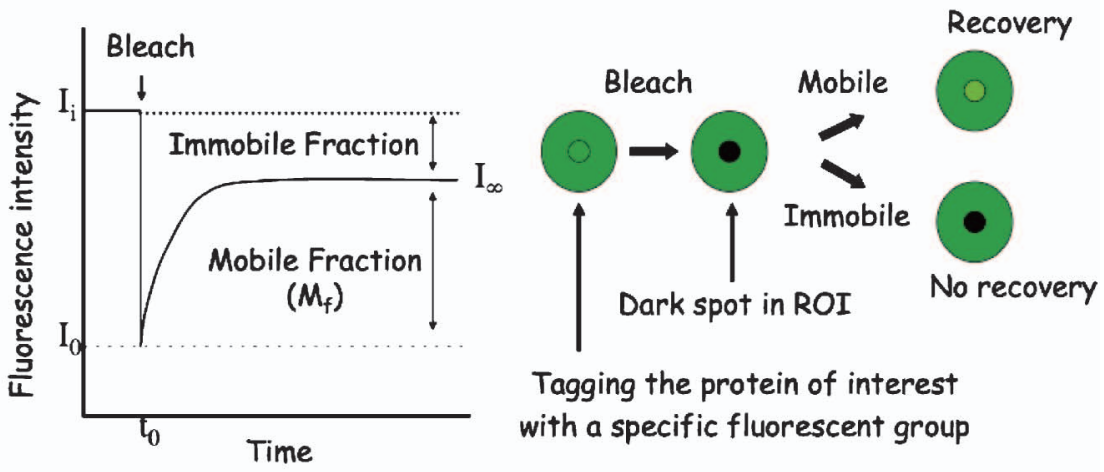

Tagging the protein of interest with a specific fluorescent group

$$
M_{f}=\frac{\left(I_{\infty}-I_{0}\right)}{\left(I_{i}-I_{0}\right)}
$$

Fig. 1. FRAP System

FRAP techniques needed to tagging the membrane protein of interest, with a specific fluorescent group and bleaching the fluorescent group in a small area by laser. If target protein was immobile, bleach area was stably dark (Upper panel; Cav-1-GFP). However, target protein was mobile, bleach area's fluorescence intensity was recovered, meaning its protein was diffused (Upper panel; IR-GFP) (A). In this study, measurement of the lateral diffusion of the IR was performed by fitting analysis to fluorescence recovery curves, which provided $\mathrm{M}_{\mathrm{f}}$ (ratio of mobile fraction) and the diffusion constant (B).

結果，中性アミノ酸であるバリン，セリン，グルタ ミンに置換した IR-GFP 変異体すべてにおいて, 蛍光回復率の低下がみられた（Fig. 4)。以上の結 果から，GM3 の発現上昇によって IR $\beta$ サブユニッ トの細胞膜直上のリジン残基と GM3 のシアル酸残 基の静電的相互作用が増大した結果，IR-Cav1 複合 体が解離する分子機構が明らかにされた。筆者は上 皮成長因子受容体（EGFR）や血小板由来成長因子 受容体（PDGFR）などの成長因子受容体において も，膜直上の塩基性アミノ酸残基が酸性糖脂質の形 成する環境場と静電的に相互作用していることを想 定しているが, ${ }^{3}$ 最近になり Simons らの研究によ
り EGFR の細胞膜直上に存在するリジンをグルタ ミンに変異させると GM3 との相互作用が減少する ことも示された. ${ }^{9}$

2-3. 細胞膜の脂質組成変化によるインスリン受 容体の動態解析 このメカニズムをさらに詳細に 検討していくために，IR の膜上での動態が脂質組 成の変化によりどのような影響を受けるのかを測定 した。まず，IR-EGFP の安定発現株を CHO-K1 細 胞を用いて作成し，蛍光標識した受容体がインスリ ンにより活性化することを確認した（Data not shown)。次に細胞株に対して FRAP 計測を行った.

測定には共焦点レーザー走査型顕微鏡（Olympus 

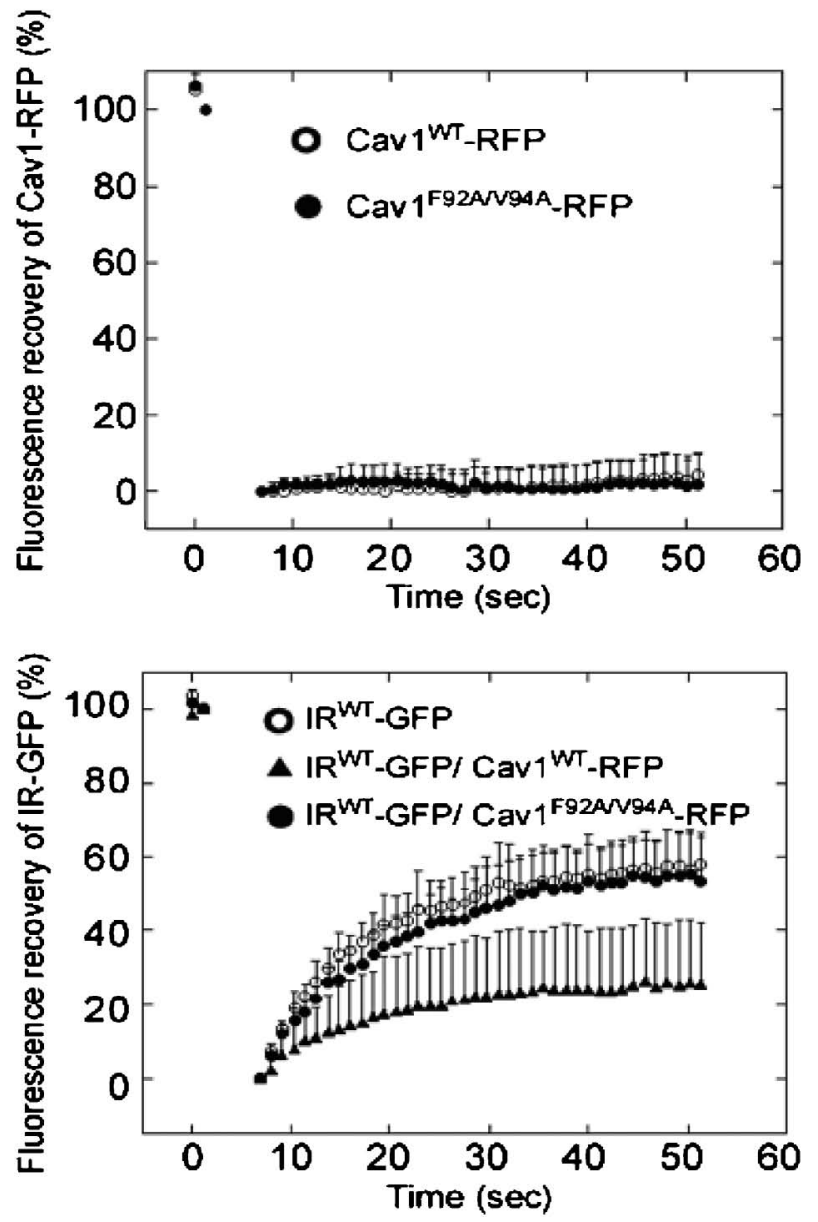

Fig. 2. Immobilization of IR by Cav1 in Living Cells

The fluorescence recovery of Cav1-RFP (Upper; open circle) or the Cav1-RFP mutant (Upper; closed circle) co-expressed with IR-GFP, and the fluorescence recovery of IR-GFP expressed alone (Lower; open circle) or coexpressed with Cav1-RFP (Lower; triangle) or the Cav1-RFP mutant (lower; closed circle) were measured.
A

\begin{tabular}{|c|c|c|c|}
\hline ...SNIAK & $T \mathrm{M}$ & RKRQP & GFP \\
\hline ...SNIAR & $T M$ & KRQP & GFP \\
\hline ... SNIAV & $T M$ & KRQP & GFP \\
\hline SNIAS & TM & KKRQP & GFP \\
\hline SNIA & TM & $K R Q P$ & GFP \\
\hline
\end{tabular}

IR ${ }^{W T-G F P}$ IR R944R_GFP $^{-}$ IR K944V_GFP IR K944S_GFP IR ${ }^{\text {K944G_GFP }}$ neutral amino acid

B

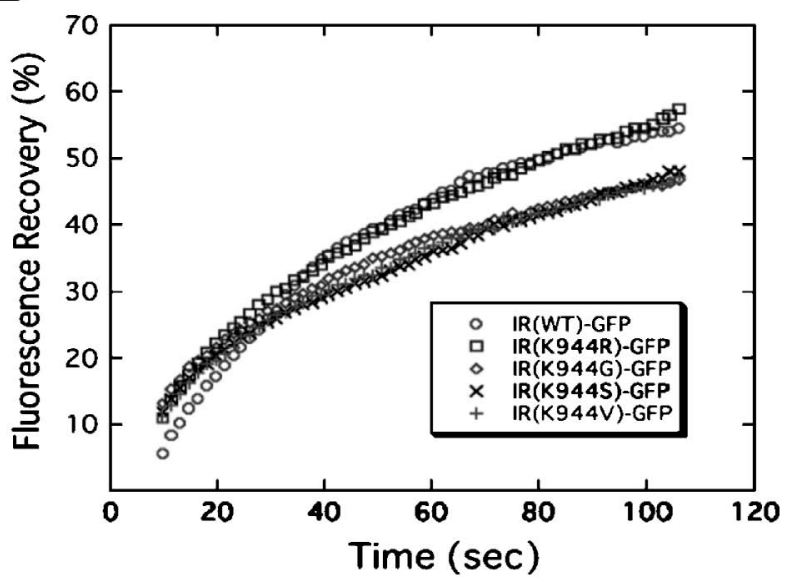

Fig. 4. The Lysine Residue IR944 is Essential for the Interaction of IR with GM3

Specificity of the interaction between lysine at IR944 and GM3 by FRAP analyses. Schematic structure of IR-GFP mutants in which the lysine at IR944 is replaced with basic and neutral amino acids (A). Fluorescence recovery of IR-GFP mutants in GM3 (+) cells (B).
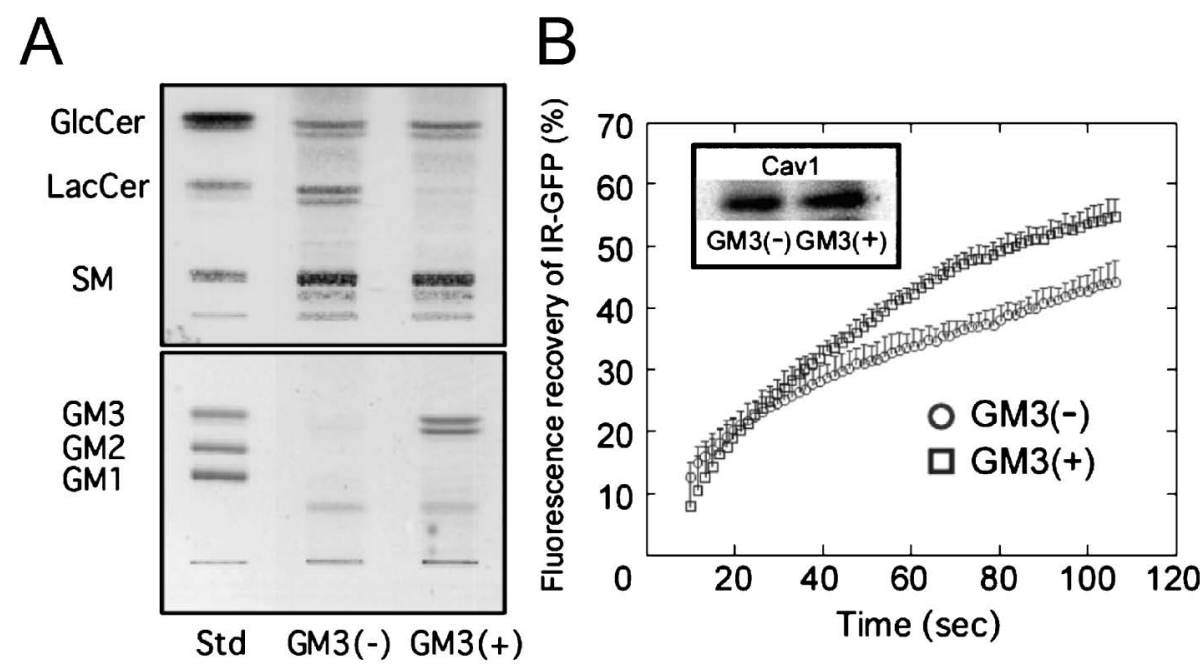

Fig. 3. Enhanced Mobility of IR in GM3-enriched Membrane

Glycosphingolipid analysis of GM3-reconstituted cells [GM3 (+)] and mock cells [GM3 (-)]. Glycosphingolipids extracted from these cells, corresponding to $1 \mathrm{mg}$ of cellular protein, were separated on HPTLC plates and stained with resorcinol- $\mathrm{HCl}$ reagent to visualize gangliosides, or with cupric acetate-phosphoric acid reagent for neutral glycosphingolipids as described in Materials and Methods (A). FRAP analyses. Shown is fluorescence recovery of IR-GFP in GM3 ( - ) and GM3 (+) cells expressing equal levels of Cav1 (Inset) (B). 
FV1000-D）を用いた。対物レンズは UPLSAPO の 60 倍水浸仕様で開口数は 1.20 , 蛍光の励起にはマ ルチアルゴンレーザー（波長 $488 \mathrm{~nm} ）$ を用いた。 イメージサイズは $512 \times 512$ pixel とし，スキャンス ピードは $4.0 \mu \mathrm{s} / \mathrm{pixel}$, ズームは 5.0 倍 $(0.082 \mu \mathrm{m} /$ pixel）に設定した。スキャン設定は，ブリーチ前 にレーザーパワー $1.0 \%$ で 5 フレーム，ブリーチ ROI の形状を円形 (radius 30 pixel $=2.46 \mu \mathrm{m}$ ) にし, レーザーパワー $100 \%$ で ROI を 3 回ブリーチした 後，レーザーパワー $1.0 \% ， 94$ フレームを取得する 条件で行った．細胞は $35 \mathrm{~mm}$ ガラス底ディッシュ に培養し，測定前にフェノール非含有培地である Opti-MEM に交換した後，顕微鏡に設置した培養 ステージにて 5 分間以上安定させた.

まず，コントロールとなる IR-EGFP 安定発現株 に対して FRAPを行い，得られた蛍光回復曲線に 対して非線形カーブフィッティング解析を行った。 カーブフィッティングとは, 実験的に得られたデー 夕に対して，決められた条件に最もよく当てはまる ような曲線を求めることで，今回筆者は，IR が細 胞膜上で複数の異なる側方拡散を行う成分に分離で きる（すなわち，細胞膜が 2 つ以上の不均質な成分 で構成され，そこをIRが拡散している) と仮定し， Fig. 5(A)のようなモデル式を当てはめた。計算に は OriginPro 8.0（Light Stone 社）を用いて最小自 乗法を使用した。その結果，IR の拡散成分が 1 成 分であると仮定したよりも，2 成分と仮定した方 が，オリジナルデータと計算結果の間の 2 乗誤差の
和を示すカイ 2 乗值 $\left(\chi^{2}\right)$ が減少することがわかり，

Fig. 5 (B) に示されるようにフィッティングカーブ も 1 成分（左図）より 2 成分（右図）の方が実測值 に重なった。このようにして成分数を増やした結果, 3 成分以降では至適な成分比が得られなかったた め，本研究では IR を 2 成分に分けて以降の検討を 行った.

今回のモデル式によるフィッティング解析から， 動的成分を $100 \%$ としたときの成分比率，蛍光回復 率の収束值（=動的比率）及び各成分が完全に蛍光 回復するまでの時間の半值（T-half）を求めた。そ の結果，遅い拡散（T-half=30.33(s)）をする成分 は $45.7 \%$ ，速い拡散（T-half = 5.54 (s)）をする成 分は $31.9 \%$ ，動的比率は 0.79 となった。

続いて膜脂質の組成を外因的に調節するために, 本研究では，コレステロースを包括し除去する試薬 である $\mathrm{M} \beta \mathrm{CD}$ と糖脂質生合成阻害剂の D-PBPP を 用いて検討を行った（Fig. 6)。 $\mathrm{M} \beta \mathrm{CD}$ が細胞の形 状及び生死に影響がない条件を種々検討した結果, 濃度及び処理時間は $5 \mathrm{~mm} 10 \mathrm{~min}$ に確定した。こ の条件において FRAP 計測を行いコントロールと 比較した結果，動的比率が 0.79 から 0.68 に減少し た。興味あることに，この時 IR の遅い成分には影 響はなく，速い成分の成分比率のみが同程度減少し ていた。また，それぞれのIR の拡散定数を算出し たところ， $\mathrm{M} \beta \mathrm{CD}$ 処理による顕著な変化はみられ なかった。一方，糖脂質生合成阻害剂である DPBPP の処理条件は常法により $20 \mu \mathrm{M} 48$ 時間で行

\section{A}

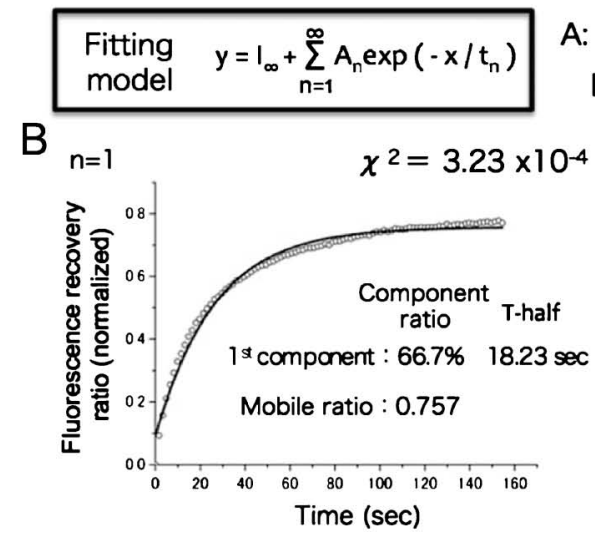

A: Component ratio T-half $=-t_{n} \ln (1 / 2)$

I.: Plateau value (Mobile ratio)

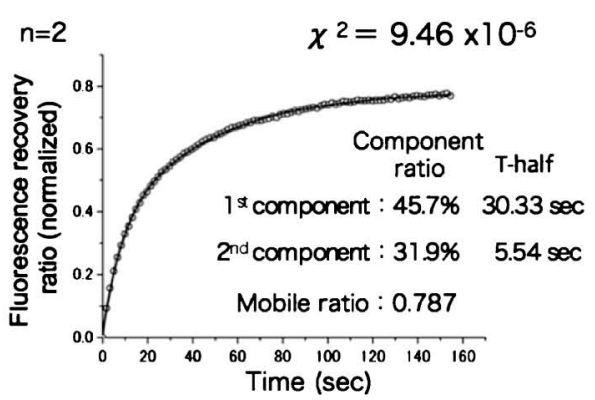

Fig. 5. Equation of Multi-component Fitting Model and Curve Fitting Analyses of Mobile Insulin Receptors

The equation of multi-component fitting model was described into the square (A). One- and two-component fits to FRAP data using OriginPro 8.0 software. Mobile molecules of IR-EGFP were separated into two components (B). 

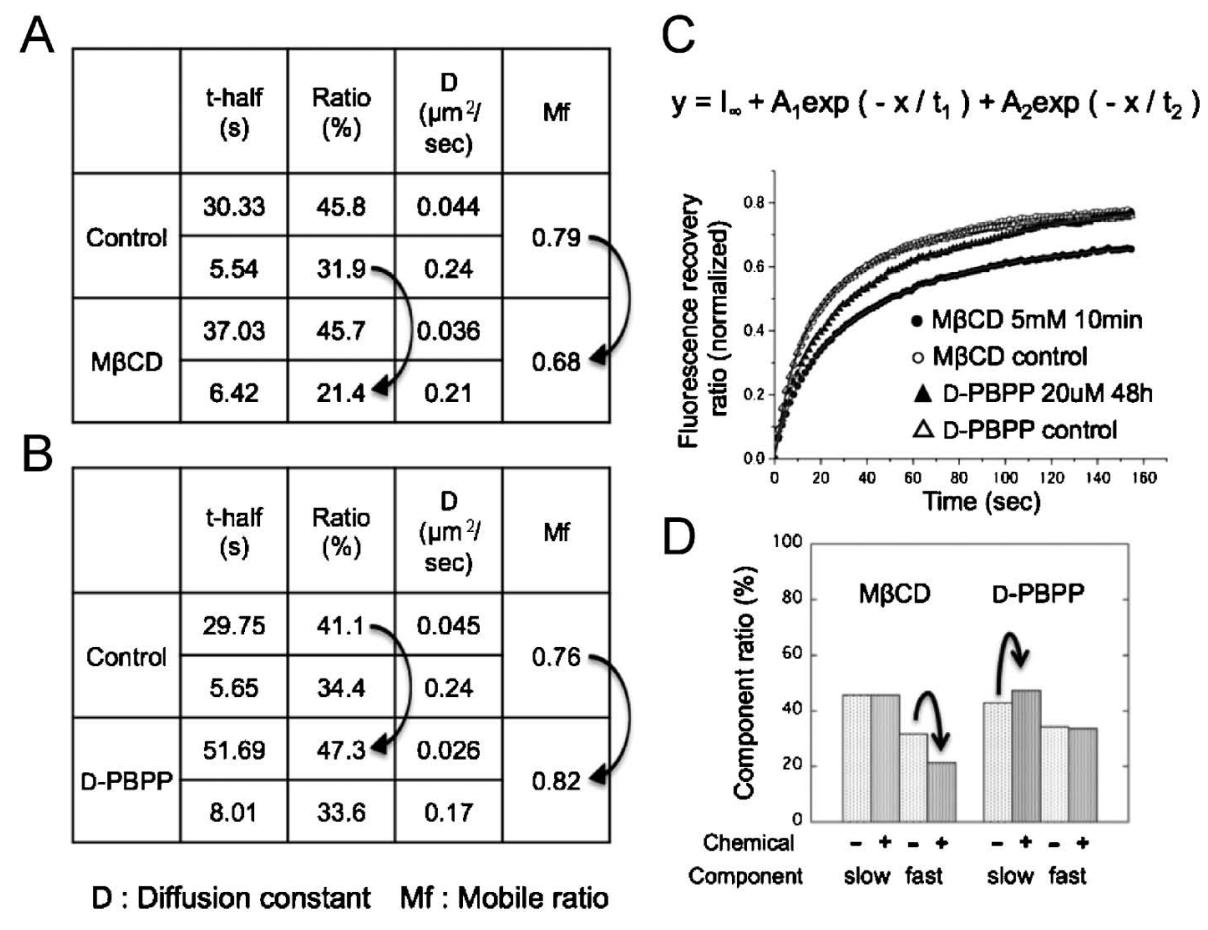

Fig. 6. Curve Fitting Analyses by Treatment with Lipid Regulators

Ratio of fast component and the $\mathrm{M}_{\mathrm{f}}$ values of IR decreased by treatment with $\mathrm{M} \beta \mathrm{CD}$ (A, D). On the other hand, Ratio of slow component and the $\mathrm{M}_{\mathrm{f}}$ values of IR increased by treatment with D-PBPP (B, D). Fluorescence recovery ratio of IR-EGFP was affected by treatment with M $\beta$ CD or D-PBPP (C) .

つた。この条件において同様に FRAP 計測を行い コントロールと比較した結果, 動的比率は $\mathrm{M} \beta \mathrm{CD}$ とは逆に 0.76 から 0.82 に増加した。この時 IR の 速い成分には影響はなく，遅い成分の成分比率のみ が同程度増加していた。 IR の拡散定数は各成分と も若干減少したが顕著なものではなかった。

また，それぞれの処理条件において，IRのイン スリン刺激による自己リン酸化を調べたところ, $\mathrm{M} \beta \mathrm{CD}$ では活性の増減は観察されなかったが $\mathrm{D}-$ PBPPでは顕著な低下がみられた(Data not shown).

この結果は, 膜受容体が脂質組成変化の影響が異 なる複数の領域（マイクロドメインを含む）に存在 し, 領域毎に受容体の活性調節が行われている可能 性を示しており，生細胞において 1 分子観察以外の 方法でマイクロドメインの存在を示す重要な証拠と なり得る。ただし FRAP から得られる情報は，そ れ自体が測定領域における「拡散の平均」を示して いるため，原理的にも多成分 fitting による解析結 果が厳密にターゲット分子を複数の速度成分に区分 けしたことにはならない。今後は新たなモデル式も 導入し, 脂質組成の違いによる受容体の流動性の変 化を解析していく予定である.

2-4. 不均質な膜分子環境における 1 粒子追跡法
の有用性全反射顕微鏡も膜受容体の側方拡散を 解析する上で有用な装置である，以前に筆者らは， 全反射顕微鏡を用いて細胞膜上の IR-GFP と Cav1GFP の動態観察を行った。 ${ }^{3)}$ しかし，拡散速度を測 定する上では GFP は退色が激しいため条件設定に 制約が生じる。そこで現在は，GFP の代わりに低 分子リガンドと特異的な共有結合を形成する夕グタ ンパク質を利用した Halo-Tag テクノロジー（プロ メガ社)を用いて，テトラメチルローダミン（TMR） を標識した IR-TMR 及び Cav1-TMR を作成し，解 析を行った。これにより標識分子の形成する粒子 （1 分子であるかどうかは検証の必要がある）の拡 散係数をヒストグラムとして表示することが可能に なる。つまり，ウエスタンブロットなどの生化学的 データが反応の平均を示しているのに対して，各々 の分子の反応パラメータの分布をみることができ る．このことは，カベオラや糖脂質マイクロドメイ ンなどが存在する不均質な膜分子環境において，受 容体の動態を調べるのに適した手法であると考えて いる.

また，拡散係数の計測においては，輝点追跡ソフ ト「G-Track（ジートラック）」(ジーオングストロー ム社）を使用することにより，画像取得後の解析ま 


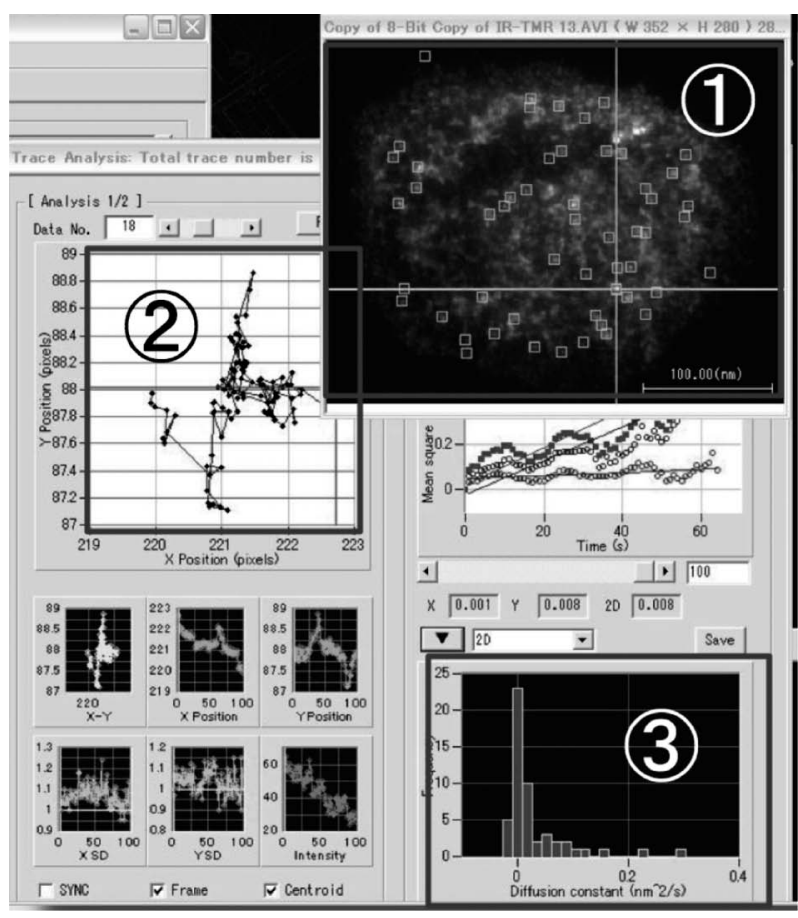

Fig. 7. Single Particle Tracking Analysis by G-track Software (1): Image stack (AVI movie). (2): Trace analysis of fluorescent spot. (3): Histogram plot of diffusion constant.

での行程をスムースに進めることが可能になった (Fig. 7).

\section{3. 展望}

このところ蛍光顕微鏡装置は, 超解像の原理を模 索し実用化していく新たな潮流がある一方で，既存 の装置をさらに使いこなすべく，解析手法やアプリ ケーションソフトの改良が施され，イメージングの 機器から計測機器へと日々発展を遂げている感もあ る。上述したように FRAP 法も蛍光回復曲線に対 し非線形カーブフィッティングを行うことで，異な る速度成分に分離することが可能であり，そこから 膜の質的変化を予想することができる．1 粒子追跡 法においても，拡散係数の分布をヒストグラム化し て表現することで不均質な膜環境の変化を観察する ことができる，最近では，蛍光相関スペクトル法 （FCS）の概念を二次元に拡張した画像相関スペク トル法（ICS）が話題に上るようになってきた。 と りわけ筆者は，既存の共焦点顕微鏡を用いて解析で きるラスター画像相関スペクトル法 $(\mathrm{RICS})^{10,11)}$ が 膜分子の拡散測定や相互作用解析に有用ではないか と考えており，糖脂質マイクロドメインの生命現象 への積極的な関与をこの手法で実証できないかと試 行錯誤の日々である.
謝辞本研究は札幌，仙台と場所を移しながら 常に暖かくも厳しくご指導頂いた井ノ口仁一教授 （東北薬科大学分子生体膜研究所）の下で，多くの 共同研究者とともに実施した研究を基盤とし，湘南 平塚の地で 2009 年に立ち上げた研究室において進 展させたものである．東海大学大学院工学研究科修 士課程の尾田和隆君並びに共同研究者各位にこの場 を借りて感謝申し上げたい

\section{REFERENCES}

1) Inokuchi J., Kabayama K., Trends Glycosci. Glycotechnol., 20, 353-371 (2008).

2) Yoshikawa M., Go S., Takasaki K., Kakazu Y., Ohashi M., Nagafuku M., Kabayama K., Sekimoto J., Suzuki S., Takaiwa K., Kimitsuki T., Matsumoto N., Komune S., Kamei D., Saito M., Fujiwara M., Iwasaki K., Inokuchi J., Proc. Natl. Acad. Sci. USA, 106, 9483-9488 (2009).

3) Kabayama K., Sato T., Saito K., Loberto N., Prinetti A., Sonnino S., Kinjo M., Igarashi Y., Inokuchi J., Proc. Natl. Acad. Sci. USA, 104, 13678-13683 (2007).

4) Inokuchi J., Kabayama K., Nagafuku M., Sato T., Protein, Nucleic Acid, Enzyme, 53, 1552-1557 (2008).

5) Uemura S., Kabayama K., Noguchi M., Igarashi Y., Inokuchi J., Glycobiology, 13, 207216 (2003).

6) Okamoto T., Schlegel A., Scherer P. E., Lisanti M. P., J. Biol. Chem., 273, 5419-5422 (1998) .

7) Cohen A. W., Razani B., Wang X. B., Combs T. P., Williams T. M., Scherer P. E., Lisanti M. P., Am. J. Physiol. Cell Physiol., 285, C222-C235 (2003).

8) McLaughlin S., Murray D., Nature, 438, 605611 (2005).

9) Coskun U., Grzybek M., Drechsel D., Simons K., Proc. Natl. Acad. Sci. USA, 108, 90449048 (2011).

10) Digman M. A., Brown C. M., Sengupta P., Wiseman P. W., Horwitz A. R., Gratton E., Biophys. J., 89, 1317-1327 (2005) .

11) Digman M. A., Wiseman P. W., Horwitz A. R., Gratton E., Biophys. J., 96, 707-716 (2009) 